\title{
Report on a Pilot Study to Crowdsource Farm Gate Prices for Legumes in Southern Malawi
}

\author{
Dennis O. Ochieng
}

\begin{abstract}
Little is known about farm gate prices in Malawi since data on the price trends are inconsistently collected. Yet this is important information for assessing the performance of agricultural markets. This report summarizes the findings from a pilot study to crowdsource farm gate prices for pigeon peas and chickpeas through the Farm Radio Trust (FRT) platform. In a series of radio 'jingles' and short message service (SMS) 'pushes', farmers were invited to report the prices and locations at which they had sold their pigeon peas and chickpeas to a toll-free number or using SMS. The phone numbers of farmers who responded were entered into a weekly draw with the possibility of winning a MWK25,000 coupon redeemable at a major agricultural input dealer. Between August 15, 2019 and November 1, 2019, 637 farmers called or sent short message service (SMS) texts to a toll-free number to report their sales, volume sold, and the type of buyer and location for sales of pigeon peas or chickpeas during the 2019 marketing season. At the end of the pilot, a follow up telephone survey of 468 of the 637 farmers was conducted to obtain detailed information on farmers' production and marketing activities that were not captured in the initial phone calls.

Findings show that pigeon pea and chickpea farming is dominated by men and is highly commercialized, with about 79 percent of production sold. Less than 8 percent of farmers reported sales at prices equal to or above the minimum farm gate prices announced by the Government at the beginning of main harvest season. Most of the products were sold to vendors and manufacturers, while a small proportion was sold directly to consumers who usually offered better prices than vendors and manufacturers. Farmers mainly depended on buyers for price information and less than one-half of those interviewed in the follow up survey were aware of the ruling minimum farm gate prices. Buyers mainly purchased at below these minimum prices in an environment with limited market access with fluctuating production and prices. This suggests that price support to the legume producers does not guarantee better producer prices. As long as minimum farm gate prices remain unenforceable, they need to be reformed (if not eliminated) as they are not delivering the intended benefits to smallholder farmers.
\end{abstract}




\section{Introduction}

Legumes are a major source of plant proteins and are largely grown by poor farm households in developing countries. Two of the most common legumes farmed in Malawi are pigeon peas and chickpeas. The two crops are mainly grown in the South of Malawi, largely under a rain-fed production system in diverse agroecological contexts, ranging from the arid to semi-arid areas. The two crops contribute to farm household food security and nutrition, improve incomes from crop sales and generate on-farm employment, as well as building smallholder farmers' resilience to climate change, as they thrive in areas experiencing frequent and prolonged dry spells (Monyo et al., 2015). Further, both legumes are mainly exported to India, and generate foreign exchange earnings that contribute to Gross Domestic Product (GDP) growth.

In Malawi, legume marketing trends have been variable with high price and volume seasonality depending on periodic production and marketing shocks (Monyo et al. 2014; Dzanja et al. 2016). India is the main export market for Malawi's pigeon peas, who make up 8 percent of India's import in pulses (IPGA, 2019). One significant shock occurred in the 2016 marketing season when India imposed an import quota for pigeon peas, which reduced Malawi's exports. This led to a domestic supply glut that subsequently suppressed prices. Farmers had to sell their commodities below their production costs. The substantial losses coupled with the lack of a commodity market led to reduced production in subsequent seasons (Weber and Tiba, 2017).

The legume sector in Malawi shows the usual food price policy dilemma governments face of trying to keep prices high and stable enough to incentivize producers but low enough to make them affordable to consumers (Timmer et al. 1983). The Government of Malawi also faces this dilemma and has attempted to incentivize producers by setting minimum farm gate prices, which are usually announced at the beginning $t$ of main harvest marketing season by the Ministry of Agriculture, Irrigation and Water Development (MoAIWD).

Despite the Government setting the minimum farm gate prices each marketing season, there is limited evidence of its enforcement. Besides, there is no consistent data collected on farm gate prices of all agricultural commodities in Malawi. Apart from the MoAIWD (through the Agricultural Market Information System - AMIS), no other institution in Malawi has attempted to collect data on farm gate prices for agricultural commodities across the country. Such data is very useful in analyzing the performance of markets in terms of price spreads from farm gate to consumption point and the distribution of gains across actors in the commodity value chains. This provides insights on the critical intervention areas to boost investments in agricultural value chains. However, the data that is collected has gaps because of infrequent collection.

Against this background, IFPRI conducted a pilot of crowdsourcing farm gate prices through the Farm Radio Trust (FRT) platform, where 637 farmers sent short message service (SMS) texts or called a toll-free number whenever they sold pigeon peas or chickpeas during the 2019 marketing season. A follow up survey of 468 of the 637 farmers was conducted to obtain detailed information on farmers' production and marketing activities that were not captured in the short phone calls. The two crops were chosen for the pilot crowdsourcing because of their late marketing period that peak around August-October. The aim of the study was to analyze: (1) the average farm gate prices for pigeon peas and chickpeas; (2) levels of awareness of farmers of the minimum farm gate prices and its usefulness in setting prices; (3) the extent to which farmers are paid the minimum farm gate prices; and (4), the production and marketing environment for pigeon peas and chickpeas.

The report is organized as follows. Section 2 describes the methodology used. Section 3 discusses the study findings from the crowdsourced data and a follow up survey. Section 4 concludes. 


\section{Methodology}

\subsection{Sampling procedure}

The study employed an experimental (radio and mobile phone-based) approach to crowdsource farm gate pigeon pea and chickpea prices from farmers. We raised awareness of the crowdsourcing activity among farmers in three ways. First, radio jingles (adverts) were aired four times a day at prime times across four vernacular radio stations in southern Malawi (Angaliba, Gaka, Mzati, and Neno) to inform farmers to report on their sales activities through a toll-free line or text messages. The radio stations were carefully chosen to air the jingles in different dialects in the fourteen districts shown in Figure 1. Second, text messages were 'pushed' weekly to a list of farmers in southern Malawi, obtained from the Farm Radio Trust data base of farmers. Lastly, through radio farmer programs aired by FRT, farmers were encouraged to participate in the crowdsourcing activity. The study was confined to the South of Malawi as the two crops are mainly grown there.

To encourage farmers' participation, callers were entered into a weekly draw and stood a chance of winning a coupon worth MWK25,000 (approximately US $\$ 34$ ). The winners could redeem the coupons at any store of a major agro-dealer (Agora) for agricultural inputs. This promotion and weekly draws lasted for four months (August-November 2019), with an additional grand draw during the last week of the pilot, in which the winners received MWK80,000 worth of coupons for agricultural inputs. 560 pigeon pea farmers and 77 chickpea farmers responded via phone calls or SMS by the end of the crowdsourcing pilot giving a combined baseline data of 637 farmers. Figure 1 shows the distribution of farmers by district. A follow up phone call survey was conducted during November to better understand the marketing environment of the two commodities as detailed in the following discussion. A total of 468 farmers from the baseline were interviewed for this follow up phone call survey.

Figure 1. Number of farmers by district

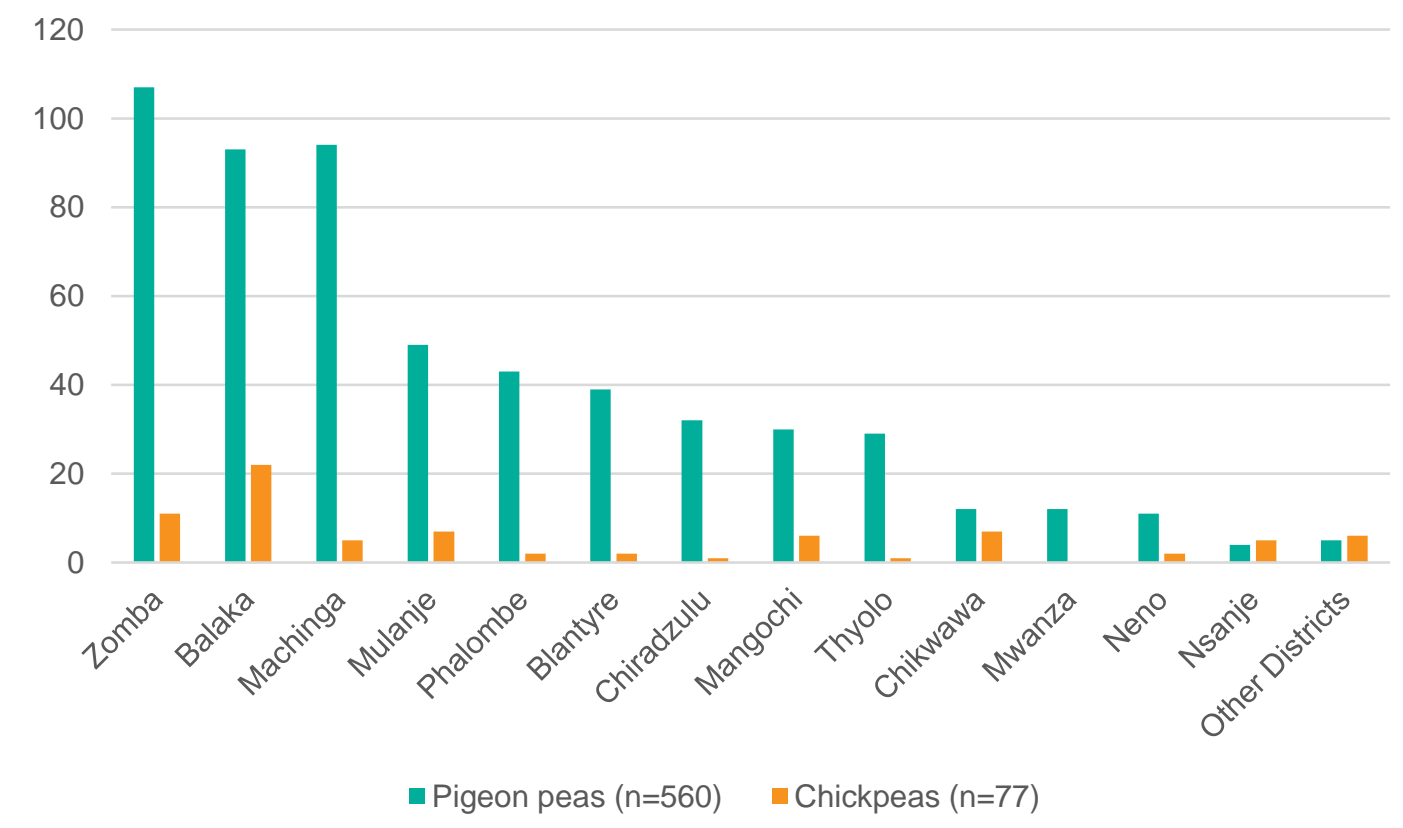

Source: Crowdsourced baseline data (August-October 2019). 


\subsection{Data}

The study used data from a two-part survey of pigeon pea and chickpea farmers in southern Malawi. The first part involved crowdsourcing of farm gate prices of the two commodities. In addition to the sales prices, farmers who called the toll-free number were asked to provide information on their gender; volumes sold; type of buyer, location of sales; and distances to and name of their nearest market. During a follow up phone call survey at the end of the pilot, farmers were asked about their age; the size of their household and farm; area of the two crops cultivated; quantities harvested, sold and retained as seed; awareness and usefulness of the minimum farm gate prices; sources of information on farm gate prices; intra-household decision making on sales and use of sales proceeds; use of the sales proceeds; and challenges in marketing the two commodities. The radio jingles, text message and questionnaire used in the study are provided as Annex 1 and Annex 2.

\subsection{Analytical procedure}

Descriptive statistics, such as frequencies, percentages and means were calculated and are presented using graphs and tables in the following section. The data collected was cleaned, coded and analyzed using STATA version 16.0 (StataCorp).

\subsection{Indicative Costs}

Excluding researcher time, the approximate cost of the crowdsourcing pilot was just under US $\$ 20,000$, of which about $\$ 7,650$ was for the cost of production and broadcasting the radio jingles, approximately $\$ 2,500$ for the SMS pushes, around $\$ 2,750$ for the Agora coupons (prizes) and the remainder for call center charges, management fees and the cost of the follow-up survey. If the costs of the follow-up survey and SMS pushes, whose effectiveness is still being evaluated, are excluded, then the total cost of the crowdsourcing exercise comes to just over $\$ 15,000$. This compares favorably with alternative modes of collecting price data from an equivalent number of farmers, such as an enumerator-based prices survey.

\section{Study findings}

This section presents first summary statistics from the baseline survey (crowdsourced data) followed by data from the follow-up phone survey (follow-up data). The results are presented in both graphs and tables.

\subsection{Baseline findings}

Here, we present farmers' profile in terms of gender and the summary statistics of buyers of the commodities, sales volumes and prices, and location of sales.

Table 1 presents statistics on the pigeon pea and chickpea farmers who participated in the crowdsourcing activity. Most of the interviewed farmers were men (82 percent). Interestingly, the ratio of men to women in the sample remained the same across commodity types. 
Table 1. Gender of farmers (in \%)

Gender

Pigeon peas $(n=560)$

Chickpeas $(n=77)$

Female

18

82

100

18

Male

Total

Source: Crowdsourced baseline data (August-October 2019).

Figure 2 presents a summary of the buyers of pigeon peas and chickpeas in the 2018/2019 marketing season as stated by farmers. Most of the two legumes were purchased by vendors (92 percent), followed by manufacturers. Less than 5 percent was purchased by consumers. This finding highlights the importance of vendors in the value chains of the two crops in Malawi, as will also be shown in the following discussion on the share of volumes traded across buyer types.

\section{Figure 2. Buyers of pigeon peas and chickpeas}

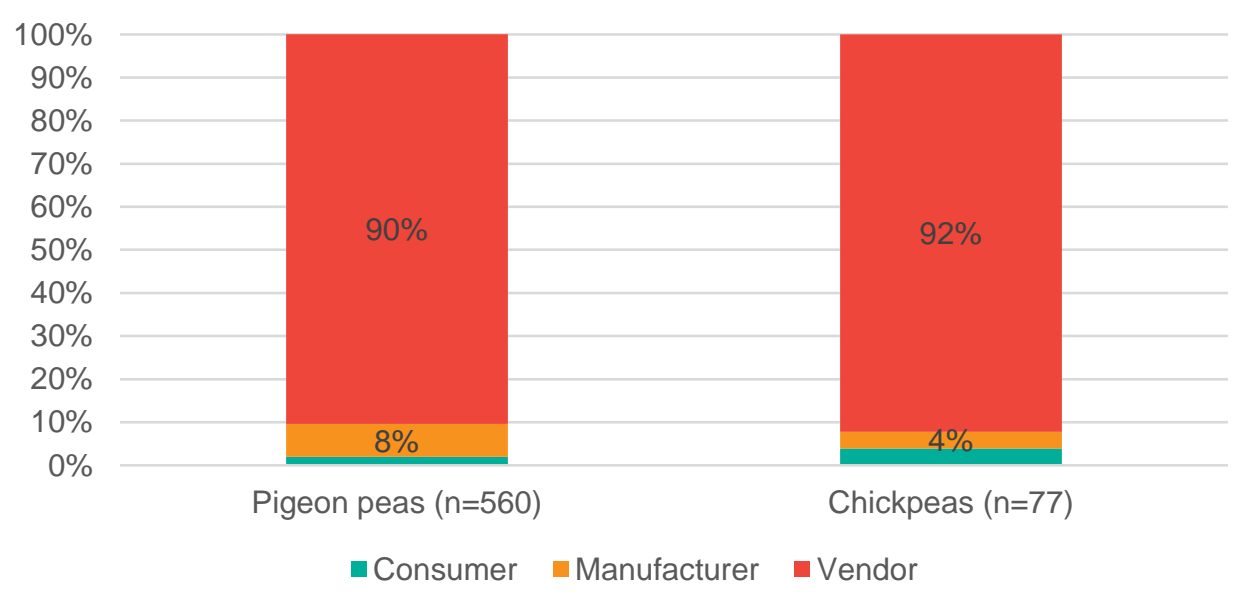

Source: Crowdsourced baseline data (August-October 2019).

Table 2 presents a summary of the average volumes in kilograms $(\mathrm{kg})$ of pigeon peas and chickpeas sold by farmers, along with the reported sales price per $\mathrm{kg}$ in Malawi Kwacha (MWK) by buyer type. The upper part of the table presents the summaries for pigeon peas (panel A) while the lower part covers chickpeas (panel B). Even though vendors dominated the supply chain in terms of sales volume, manufacturers purchased higher volumes (panel A). Volumes traded ranged from 5 to $40,000 \mathrm{~kg}$. On average, manufacturers and vendors purchased $333 \mathrm{~kg}$ of pigeon peas followed by consumers $(241 \mathrm{~kg})$. Consumers offered better average prices (MWK310) for pigeon peas than manufacturers (MWK281) and vendors (MWK253), though consumers purchased substantially lower volumes. Average prices reported ranged between MWK310/kg and MWK650/kg for pigeon peas.

For chickpeas, we see a similar trend where most volumes went to manufacturers followed by vendors and consumers (panel B). In contrast to pigeon peas volumes traded, more chickpeas were traded with the average volumes traded ranging between $70 \mathrm{~kg}$ and $650 \mathrm{~kg}$. Also, consumers offered lower prices (MWK158) than manufacturers (MWK267) and vendors (MWK202) on average. The average reported prices ranged between MWK20/kg and MWK1500/kg. 
Table 2. Sales volumes and prices of pigeon peas and chickpeas

\begin{tabular}{|c|c|c|c|c|c|}
\hline Variable & Observations & Mean & Std. Dev. & Minimum & Maximum \\
\hline \multicolumn{6}{|c|}{ Panel A: Pigeon peas } \\
\hline \multicolumn{6}{|l|}{ Quantity (kg) } \\
\hline Consumer & 11 & 241 & 285 & 5 & 1000 \\
\hline Manufacturer & 43 & 356 & 745 & 20 & 5000 \\
\hline Vendor & 506 & 333 & 1815 & 5 & 40,000 \\
\hline \multicolumn{6}{|c|}{ Price $(M W K / \mathrm{kg})$} \\
\hline Consumer & 11 & 310 & 118 & 200 & 650 \\
\hline Manufacturer & 43 & 281 & 64 & 90 & 500 \\
\hline Vendor & 506 & 253 & 67 & 31 & 600 \\
\hline \multicolumn{6}{|c|}{ Panel B: Chickpeas } \\
\hline \multicolumn{6}{|l|}{ Quantity (kg) } \\
\hline Consumer & 3 & 183 & 58 & 150 & 250 \\
\hline Manufacturer & 3 & 277 & 21 & 260 & 300 \\
\hline Vendor & 71 & 194 & 106 & 70 & 650 \\
\hline \multicolumn{6}{|c|}{ Price (MWK/kg) } \\
\hline Consumer & 3 & 158 & 210 & 25 & 400 \\
\hline Manufacturer & 3 & 267 & 153 & 100 & 400 \\
\hline Vendor & 71 & 202 & 237 & 20 & 1500 \\
\hline
\end{tabular}

Source: Crowdsourced baseline data (August-October 2019).

Notes: $\mathrm{kg}=$ kilograms; $\mathrm{MWK}=$ Malawi Kwacha.

Table 3 presents a summary of the price ranges for the two crops. Most pigeon peas were sold for below MWK300/kg, with 60 percent of transactions occurring at between MWK200/kg and MWK299/kg. Similarly, most chickpeas were also sold below MWK300/kg, with the most common price being between MWK100/kg and MWK199/kg. Just 7 percent (40 out of 560) of pigeon pea farmers and 8 percent (6 out of 77) of chickpea farmers reported sales at prices equal to or above the minimum farm gate prices announced by MoAIWD at the beginning of main harvest season. The reasons why most farmers sold their legumes at below these minimum prices will be discussed further in the next section.

Table 3. Price ranges of pigeon peas and chickpeas (in \%)

\begin{tabular}{lcc} 
Price ranges & Pigeon peas $(\mathrm{n}=560)$ & Chickpeas $(\mathrm{n}=77)$ \\
\hline$<\mathbf{1 0 0}(\mathbf{M W K} / \mathbf{k g})$ & 0.89 & 5.19 \\
$\mathbf{1 0 0}$ to $\mathbf{1 9 9}(\mathbf{M W K} / \mathbf{k g})$ & 10.71 & 44.16 \\
$\mathbf{2 0 0}$ to $\mathbf{2 9 9}(\mathbf{M W K} / \mathbf{k g})$ & 59.64 & 40.26 \\
$>\mathbf{3 0 0}(\mathbf{M W K} / \mathbf{k g})$ & 28.75 & 10.39 \\
Total & 100.00 & 100.00 \\
\hline
\end{tabular}

Source: Crowdsourced baseline data (August-October 2019). 
Table 4 summarizes the reported location of sales. Most of sales were made at the farm gate followed by a nearby market, with agro-dealers' depots a distant third. Less than ten percent of farmers reported sales at other locations. Some liquidity-constrained farmers usually make informal agreements with agro-dealers to be provided with agricultural inputs such as fertilizers, seeds and other crop chemicals in exchange for a proportion of the harvest. This may partly explain the reported sales to agro-dealers, but there are other large agro-dealers too who do not have such arrangements with farmers. The findings highlight limited smallholder farmers' access to structured markets in Malawi and the limited organized marketing through cooperatives to facilitate access to structured markets.

Table 4. Location of sales (in \%)

\begin{tabular}{lll}
\hline Farm gate & 46.3 & 51.9 \\
\hline Nearby market & 42.1 & 37.7 \\
\hline Agro-dealers' depot & 4.1 & 1.3 \\
Farm gate and nearby market & 2.9 & 2.6 \\
\hline NASFAM Depot & 1.1 & 0.0 \\
\hline ADMARC & 1.1 & 0.0 \\
\hline Private traders' depot & 0.7 & 0.0 \\
\hline Vendor's home & 0.7 & 1.3 \\
\hline Roadside & 0.5 & 2.6 \\
Cooperative & 0.4 & 1.3 \\
\hline NGOs & 0.2 & 1.3 \\
\hline Orphanage & 0.0 & 100.00 \\
\hline Total & 100.00 & 0.0 \\
\hline
\end{tabular}

Source: Crowdsourced baseline data (August-October 2019).

\subsection{Follow up findings}

This section presents results from the follow-up phone survey with 468 of the 637 farmers who participated in the crowdsourcing activity. More information was collected in the follow-up phone survey than could be obtained at the time farmers first called in to report the prices at which they sold they pigeon peas and chickpeas. This include questions on the farmers' household and land, further details on production and marketing of the two legumes commodities, and awareness and use of the minimum farm gate prices in price setting by farmers (see Annex 2).

Table 5 presents a farmer profile, including household characteristics (such as the age of household head, household size), farm characteristics (such as farm size, area under the two crops), quantities harvested, yield and average sales. On average, household heads were 37 years old, with the youngest aged 18 years and the oldest 77 years. The average farm household and comprised 6 members, farming about 2.4 acres of farmland. Both pigeon peas and chickpeas are farmed on plots of about one acre with some farmers farming on as small as 0.1 acres while others are as large as 10 acres. This suggests that the two crops are grown on relatively small parcels of land. 
In terms of output, farmers harvested about $305 \mathrm{~kg}$ (or six $50 \mathrm{~kg}$ bags) of pigeon peas and $122 \mathrm{~kg}$ (or 5.5 bags) of chickpeas. The average self-reported yield for pigeon peas was about $366 \mathrm{~kg} / \mathrm{acre}$ and $225 \mathrm{~kg} / \mathrm{acre}$ for chickpeas. The average volume sold at one time was almost $197 \mathrm{~kg}$ (about four $50 \mathrm{~kg}$ bags of pigeon peas or chickpeas). The average one-time traded volumes are relatively low.

Table 5. Descriptive statistics

\begin{tabular}{|c|c|c|c|c|c|}
\hline Variable & Observations & Mean & Std. Dev. & Minimum & Maximum \\
\hline Age of household head (years) & 468 & 36.7 & 10.4 & 18.0 & 77.0 \\
\hline Household size (number) & 468 & 5.5 & 1.9 & 1.0 & 12.0 \\
\hline Farm size (acres) & 468 & 2.4 & 2.3 & 0.5 & 30.0 \\
\hline Acreage of pigeon peas & 448 & 1.0 & 0.8 & 0.1 & 10.0 \\
\hline Acreage of chickpeas & 233 & 0.7 & 1.7 & 0.2 & 25.0 \\
\hline Pigeon pea harvested (kg) & 448 & 304.6 & 500.3 & 20.0 & 6000.0 \\
\hline Pigeon peas yield (kg/acre) & 448 & 366.3 & 510.6 & 20.0 & 6400.0 \\
\hline Chickpeas harvested (kg) & 233 & 122.3 & 120.5 & 2.0 & 750.0 \\
\hline Chickpeas yield (kg/acre) & 233 & 225.0 & 212.2 & 4.0 & 1400.0 \\
\hline Average sale at ago $(\mathbf{k g})$ & 468 & 196.7 & 306.3 & 5 & 5000.0 \\
\hline
\end{tabular}

Source: Follow-up survey data (November 2019).

Figure 3 presents statistics on the utilization of the harvested crops. Most of the pigeon peas and chickpeas farmers harvested were sold (79 percent). About 15 percent of pigeon peas and 17 percent of chickpeas were retained for seed, respectively. Only limited volumes were retained for consumption. This is plausible, given the susceptibility of the two crops to insect damage and the poor storage practices of many farmer. Liquidity constraints may have led some farmers to make to 'distress sales' at lower prices in order to pay off debts or pay school fees (Dillon, 2017). Hence, farmers usually do not store the two legumes for long time periods.

Figure 3. Utilization of pigeon peas and chickpeas harvested

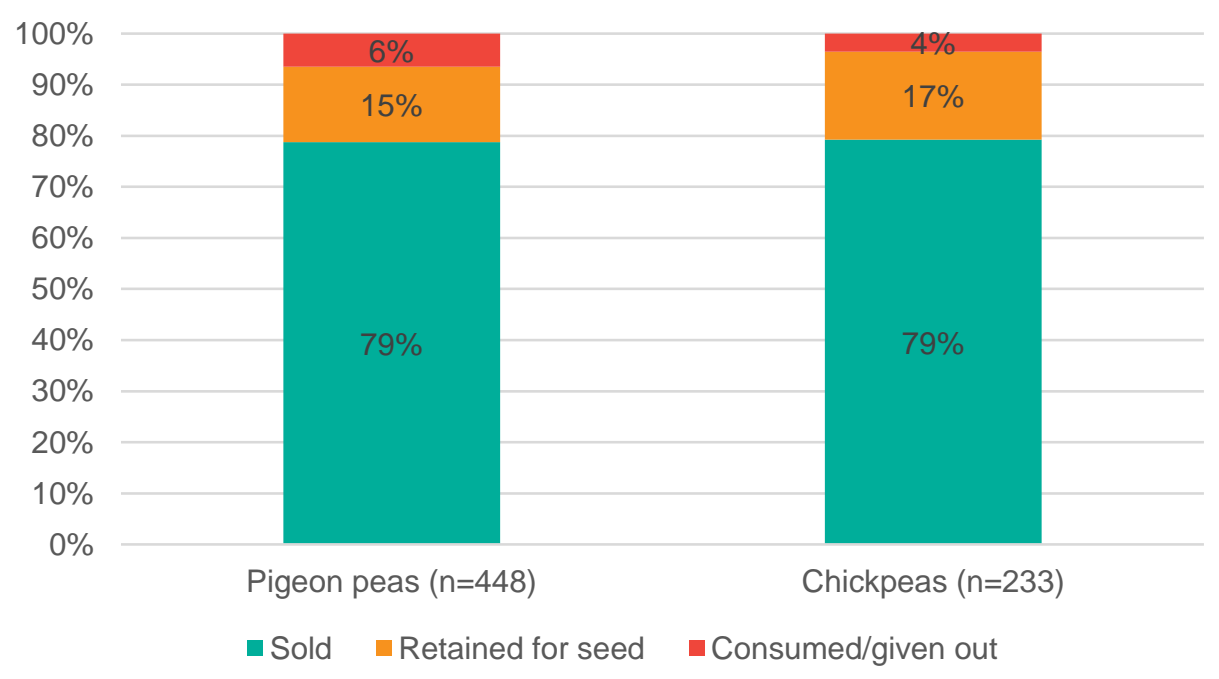

Source: Follow-up survey data (November 2019). 
Figure 4 presents the sources of information on pigeon pea and chickpea prices that were stated by farmers. Most farmers obtained price information from buyers (56 percent) followed by radio. As shown in Table 2, buyers were mainly vendors, consumers and occasionally manufacturers/processors. Access to price information through other channels (such as local extension, the Agricultural Development and Market Corporation (ADMARC) and digital platforms such as call centers) was reported by less than 10 percent of farmers. Other traders referred to the National Smallholder Farmers Association of Malawi (NASFAM), Agora Limited, the Agricultural Commodity Exchange for Africa (ACE), and Export Trading Group (ETG). Some of these entities, such as NASFAM and ACE, have digital platforms through which they disseminate price information to farmers.

Figure 4. Sources of price information

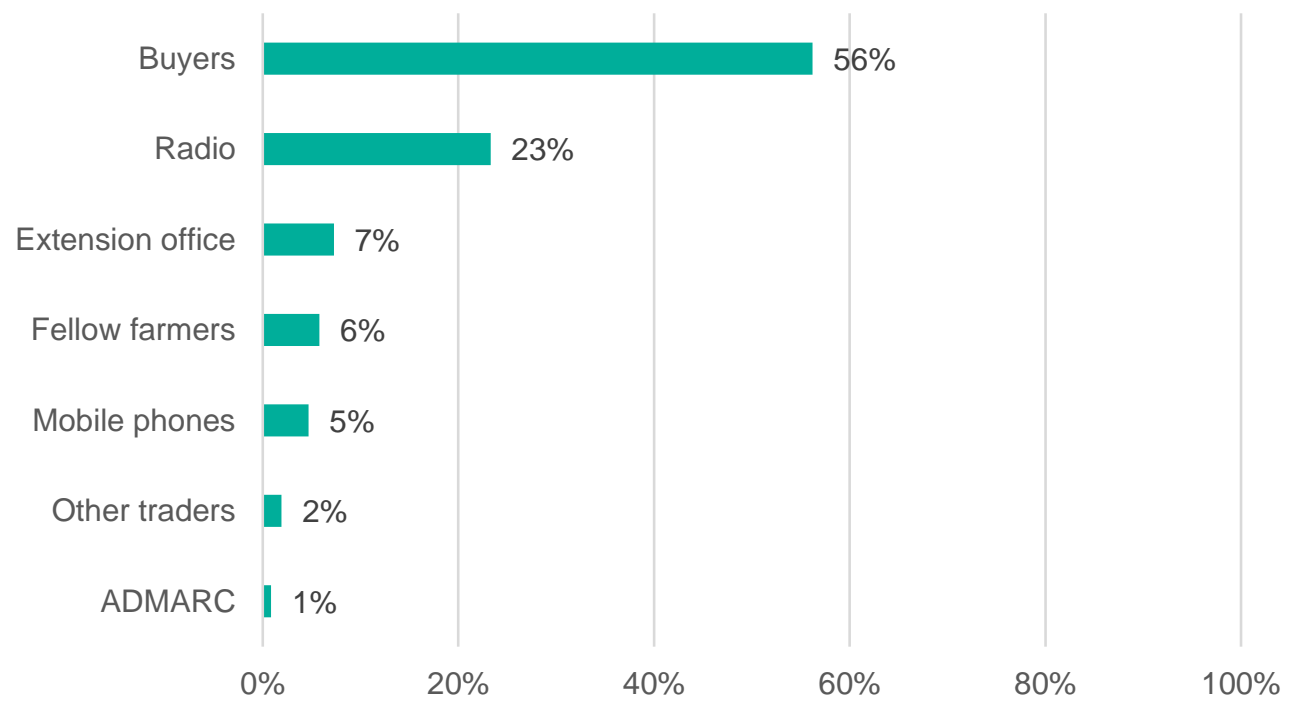

Source: Follow-up survey data (November 2019).

Figure 5 presents a summary of the percentage of farmers that were aware of the minimum farm gate prices (MFG), as well as the proportion of farmers that could accurately state the current MFG prices (MWK330/kg for pigeon peas and MWK310/kg for chickpeas). Less than half of farmers were aware of MFG prices. The proportion of farmers who were aware of the minimum prices of pigeon peas prices was 33 percent higher than for chickpeas. Interestingly, even those who mentioned that they were aware of MFG prices, gave largely inaccurate responses about the current MFG. In fact, only 1 percent of the those who were aware of the pigeon pea farm gate price gave the accurate price. None of those who were aware of chickpea MFG price could state it accurately. This points to widespread lack of information on the minimum farm gate prices announced by MoAIWD, which is plausible given farmers' limited access to other sources of price information besides buyers. 
Figure 5. Awareness and accuracy of the minimum farm gate prices of pigeon peas and chickpeas

Awareness

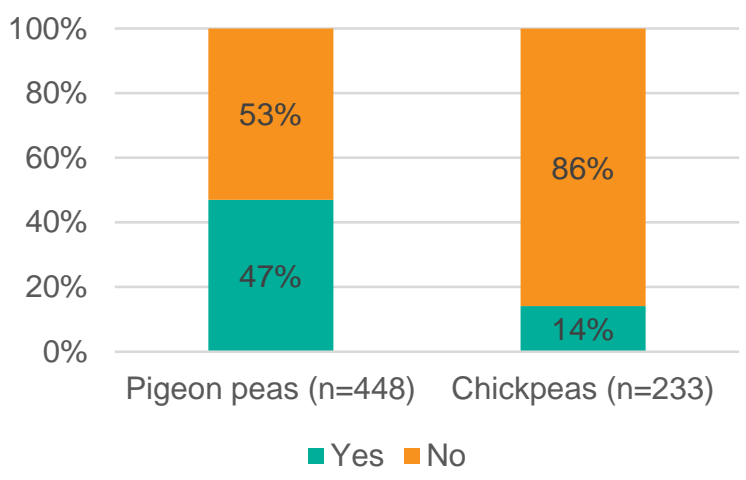

Accuracy of the miminum prices stated

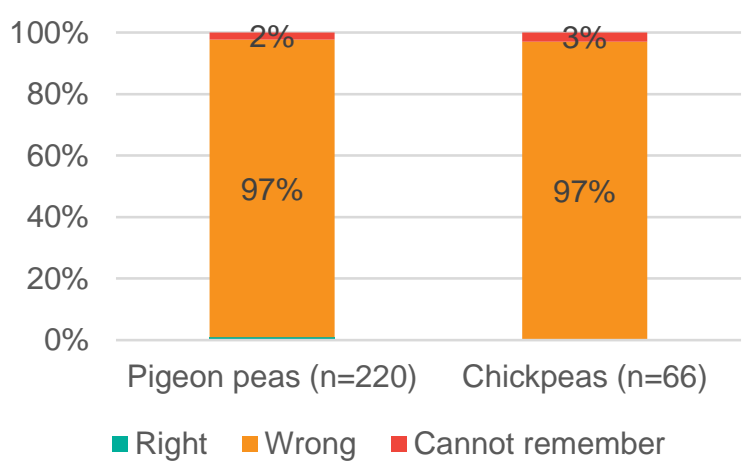

Source: Follow-up survey data (November 2019).

Figure 6 presents farmers' responses on usefulness of MFG prices in the setting prices of pigeon peas and chickpeas, and the reasons stated as to why the information was not useful. Of those who were aware of the minimum prices, only 37 percent found them useful in setting their sales prices. Of the 297 farmers who did not find the information useful, the main reason was that the timing of the information reported was different from the timing of their marketing activities. About 76 percent of farmers reported that buyers bought the commodities before MFG prices were announced, while 16 percent of them mentioned that market prices offered by buyers were below the set MFG prices. Hence, the minimum farm gate prices were not useful to many farmers in setting their sales prices in general. Also, there were instances where the information was not useful because buyers offered better prices.

Figure 6. Usefulness of minimum farm gate prices

Is the farm gate price useful for negotiating sales prices?

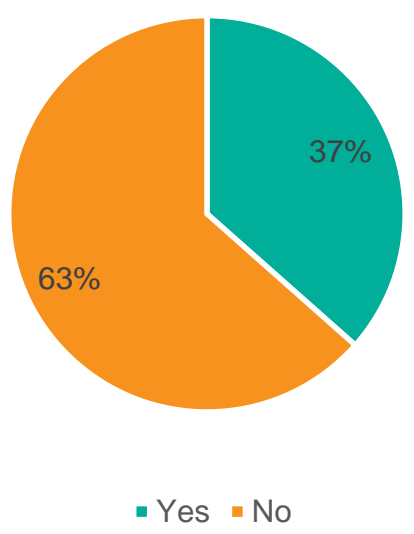

Source: Follow-up survey data (November 2019).
Why is the price not useful?

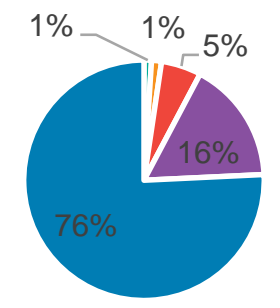

- Price was set in a pre-season agreement

- Failure to open ADMARC in time

- Buyers offer higher than the MFGP

- Buyers offer lower than the MFGP

- Buyers buy before MFGP announcement 
Farmers were asked about the month in which they sold most of the two commodities in a typical agricultural season. Table 6 shows that most farmers sold their legumes in July (34 percent) followed by August (30 percent). This shows that much of the crop is sold early in the season and that not much is left towards the end of the year, which usually coincides with the lean season in Malawi.

Table 6. Month of the highest sales volumes of pigeon peas and chickpeas

\begin{tabular}{lcc} 
Month & Frequency & Percentage \\
\hline July & 159 & 34.0 \\
August & 140 & 29.9 \\
\hline June & 66 & 14.1 \\
September & 61 & 13.0 \\
\hline October & 16 & 3.4 \\
May & 15 & 3.2 \\
\hline April & 8 & 1.7 \\
December & 1 & 0.2 \\
January & 1 & 0.2 \\
\hline November & 1 & 0.2 \\
\hline Total & 468 & 100 \\
\hline
\end{tabular}

Source: Follow-up survey data (November 2019).

Table 7 presents results on decision-making within the household on the sale of the two commodities and subsequent use of the sales proceeds. Most of the decisions on sales and use of the sales proceeds were jointly made by the household head and spouse. However, more joint decisions were made on the use of sales proceeds (72 percent) than on actual sales (61 percent). In contrast, more household heads made decisions on sales (33 percent) than on the use of the sales proceeds (22 percent). Strikingly, the proportion of farm households where household heads decided on sales and use of sales proceeds was higher than that of spouses by 30 percent and 18 percent, respectively.

Table 7. Decision-making on sales and use of sales proceeds

\begin{tabular}{lcccc|c|} 
& \multicolumn{2}{c}{ Sales } & \multicolumn{3}{c}{ Use of sales proceeds } \\
Decision maker & Observations & Percentage & Observations & Percentage \\
\hline Household head and spouse & 285 & 61 & 337 & 72 \\
\hline Household head & 155 & 33 & 103 & 22 \\
\hline Spouse & 16 & 3 & 19 & 4 \\
\hline Another adult household member & 12 & 3 & 9 & 2 \\
\hline Total & 468 & 100 & 468 & 100 \\
\hline
\end{tabular}

Source: Follow-up survey data (November 2019). 
Farmers were asked to mention the two most important uses of the proceeds from pigeon pea and chickpea sales. Numerous reasons were mentioned but for brevity, we present the two most cited reasons stated by at least 5 percent of the farmers. As shown in Figure 7, most farmers used the proceeds from legume sales to purchase farm inputs or for household expenditures (21 percent). In addition proceeds were used to buy food and pay for school fees and related expenses.

Figure 7. Most cited use of sales proceeds

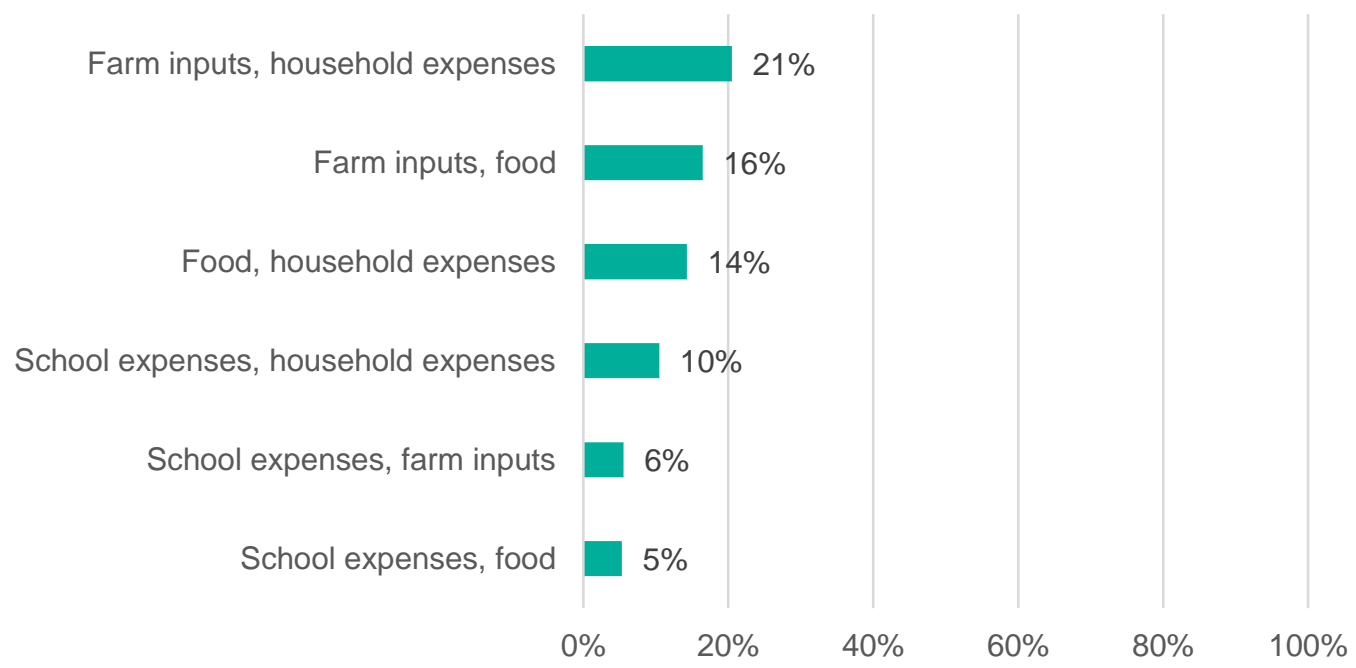

Source: Follow up survey data (November 2019).

Figure 8 presents a summary of the most cited challenges in marketing of pigeon peas and chickpeas. Again, responses are limited to challenges mentioned by at least 5 percent of farmers. Almost one-half of the farmers cited low prices and lack of markets as their most pressing challenges. Other challenges mentioned included pests and diseases affecting crops in the field, and crop pests damaging stored crops, as well as climate change and weather variability. The latter adversely affects rain-fed production of the two crops when precipitation is erratic. Above normal rainfall and flooding leads to crop losses in the fields, particularly in the flood-prone areas in southern Malawi that are large producers of pigeon pea and chickpeas.

Figure 8. Challenges in marketing pigeon peas and chickpeas

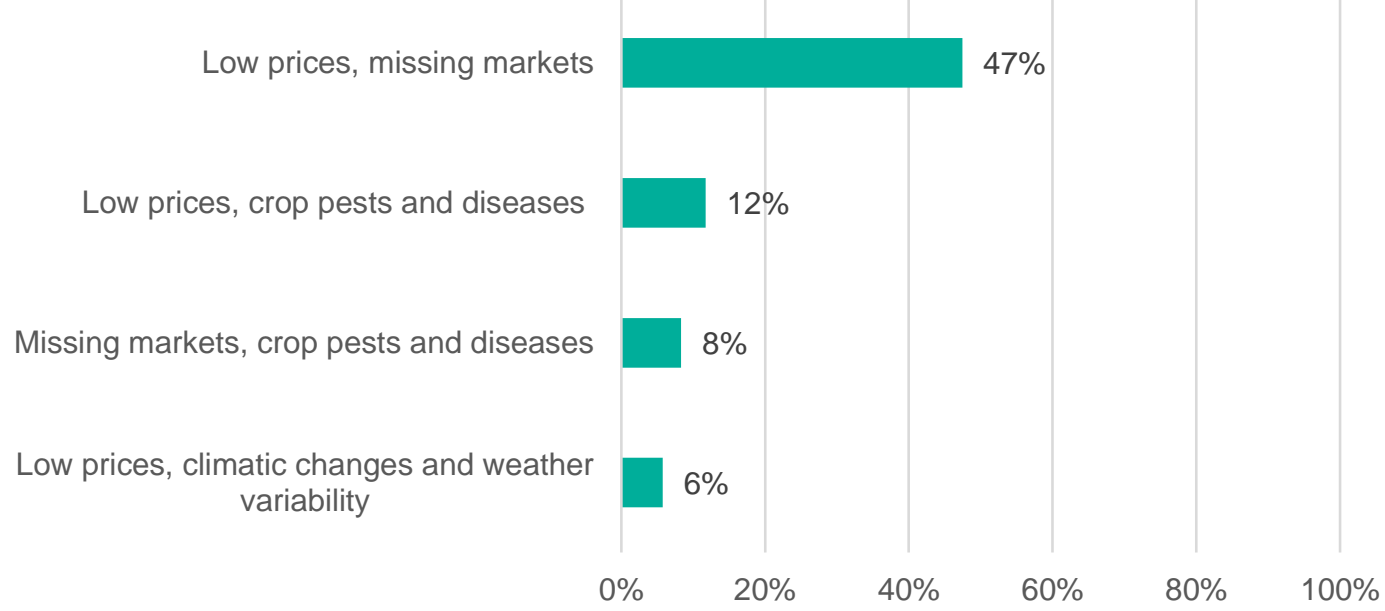

Source: Follow up survey data (November 2019). 


\section{Conclusion}

This pilot study crowdsourced farm gate prices of pigeon peas and chickpeas in southern Malawi during the 2019 marketing season and analyzed the extent to which the producers of the two products sell at prices above the set minimum farm gate prices. Through phone interviews with farmers, we established that most of the two products are sold either on farm or at nearby markets and are mainly sold to vendors and manufacturers. Some consumers also purchased small quantities directly from producers. The two legumes are mostly sold below the minimum farm gate prices of MWK330/kg for pigeon peas and MWK310/kg for chickpeas. Less than 8 percent of reporting farmers sold their pigeon peas and chickpeas at prices equal to or higher than the minimum farm gate prices. Even though consumers purchased minimal quantities, they tended to offer better prices than vendors and manufacturers. Farmers mainly sourced price information from buyers. More than half of reporting farmers were unaware of the set farm gate prices. However, those who were aware of them could not accurately state them. This is plausible given that farmers largely depended on buyers to get price information.

We also found that most farmers sell at below the minimum farm gate prices set by the Government because their access to alternative markets is limited and volumes traded are low. These findings suggest that setting minimum farm gate prices in a liberalized economy is not a panacea for the market imperfections that distort prices and pervade the markets for most agricultural products in Malawi (Ochieng et al. 2019). Producer access to market information must be widened while minimum farm gate prices should either be enforced or eliminated altogether. Expanding export markets beyond the Indian market should also benefit pigeon peas and chickpea producers, who reported limited demand the two in the domestic market.

Finally, given the relatively modest cost of conducting this pilot study, we believe that the use of radio advertising of a competition with prizes given to farmers who call a dedicated phone line to report prices, deserves consideration for future monitoring of farm gate prices for other crops in Malawi. An alternative method of conducting such a competition is to make SMS 'pushes' to a database of farmers' cell phone numbers but the cost-effectiveness of this method depends critically on the accuracy and completeness of the database used. 


\section{Annex 1. Crowdsourcing radio jingle and text message}

\begin{tabular}{|c|c|}
\hline \multicolumn{2}{|l|}{ Radio Jingle/Promo } \\
\hline English & Chichewa \\
\hline $\begin{array}{l}\text { Farmers who grew pigeon peas/chickpeas in } \\
\text { this growing season, have already sold your } \\
\text { produce? Where did you sell? How much did } \\
\text { you sell your produce for? Tell us by calling } \\
8111 \text { on Airtel toll free line. You will automati- } \\
\text { cally join a raffle draw and stand a chance to } \\
\text { win a voucher of farm inputs worth } \\
\text { MWK25,000 from Agora shops. Every week, } \\
6 \text { lucky callers will stand a chance to win this } \\
\text { voucher. This raffle draw runs up to Novem- } \\
\text { ber } 1,2019 \text {. Remember to call } 8111 \text { on Airtel } \\
\text { toll free line to enter the raffle draw. Terms } \\
\text { and conditions apply. } \\
\text { This message is brought to you by Farm Ra- } \\
\text { dio Trust in collaboration with IFPRI. }\end{array}$ & $\begin{array}{l}\text { Kodi alimi amene munalima nandolo kapena } \\
\text { nseula, mwagulitsa kale? Mwagulitsa kuti? } \\
\text { Nanga mwagulitsa ndalama zingati. } \\
\text { Tiuzeni poimba phone mwaulere ndi airtel pa } \\
8111 \text { ndipo mulankhula ndi alangizi. } \\
\text { Mukatero, ndiye kuti mwalowa mu mpikisano } \\
\text { umene alimi } 6 \text { amphumi sabata iloyonse } \\
\text { azipasidwa vocha ya K25,000 kwacha } \\
\text { yogulira kaundu wa Ulimi m'ma shop a } \\
\text { Agora. } \\
\text { Mpikisanowu ulipo mpaka September } 2019 \text {. } \\
\text { Kumbukirani kuyimba phone pa } 8111 \text { pa } \\
\text { nambala za airtel mwaulere kuti mulowe mu } \\
\text { mpkikisanowu. } \\
\text { Ndondomeko za mpikisanowu zizatsatidwa. } \\
\text { Akupatsanirani uthengau ndi a Farm Radio } \\
\text { Trust mogwirizana ndi IFPRI }\end{array}$ \\
\hline \multicolumn{2}{|l|}{ Text message } \\
\hline $\begin{array}{l}\text { Did you grow pigeon peas or chickpeas and } \\
\text { sold your produce? Where did you sell? Tell } \\
\text { us by calling } 8111 \text { on Airtel toll free line and } \\
\text { stand a chance to win a voucher for farm in- } \\
\text { puts worth MWK25,000. Farm Radio }\end{array}$ & $\begin{array}{l}\text { Kodi munalima nandolo kapena nseula ndipo } \\
\text { mwagulitsa? Mwagulitsa kuti? Tiuzeni } \\
\text { poyimba mwaulere ndi airtel pa } 8111 \text { ndipo } \\
\text { muzakhala ndi mwayi wopata mphoto za zi- } \\
\text { pangizo zaulimi zokwana K25,000.00. Farm } \\
\text { Radio }\end{array}$ \\
\hline
\end{tabular}




\title{
Annex 2: Follow up questionnaire
}

\author{
International Food Policy Research Institute (IFPRI)
}

Crowdsourcing legume farm gate prices in Malawi

November 2019

\begin{abstract}
Hello I am calling you from Farm Radio Trust, Lilongwe. Farm Radio Trust has been partnering with IFPRI to crowdsource farm gate prices for pigeon peas and chickpeas in Malawi through the radio and our call center. Thank you for telling us prices at which you sold pigeon peas/chickpeas this season. As a follow up, we kindly request you to answer a few questions regarding pigeon pea/chickpea marketing to help us understand better the marketing environment. Your responses will be kept CONFIDENTIAL and your identity will not be revealed to anyone. Your participation shall in no way affect your marketing activities. You can choose to answer or not to answer any of the questions. If you are willing to participate, shall we proceed? Yes No
\end{abstract}

\section{MODULE A: Basic information}

Age (or year born):

Education level (years of schooling):

Farming experience (years):

Number of people in the household:

Number of family members under 5 years old:

Farm size (acres):

Acreage (in acres) under this crop in the last season? Pigeon peas _ Chickpeas _

Quantity harvested of this crop (in kg) Pigeon peas Chickpeas

Quantity sold of this crop (in kg) Pigeon peas ___ Chickpeas

Quantity set aside as seed (in $\mathrm{kg}$ ) Pigeon peas Chickpeas

\section{MODULE B: Crop marketing}

1. Where do you source information on pigeon pea or chickpea prices?

i) Extension office

ii) Mobile phone updates

iii) Fellow farmers

iv) Buyers

v) Radio

vi) Other (specify)

2. Are you aware of minimum farm gate prices for pigeon peas/ chickpeas? $1=y e s 2=$ No

3. If yes, what is the minimum farm gate price for pigeon peas _chickpeas_?

4. Is the minimum farm gate price useful in setting your sales price? $1=y e s \overline{2=N o}$

5. If no, Why?

i) Buyers do not accept to buy at the set minimum prices

ii) Price was set in a pre-season agreement/contract with a buyer 
iii) Buyers offer higher than the minimum farm gate price

iv) Other (specify)

6. Were buyers willing to buy at or above the minimum farm gate price? $1=y e s 2=$ No

7. In which month do you usually sell most of the pigeon peas/chickpeas? $[1=$ Jan, $2=$ Feb, $\ldots, 12=$ Dec]

8. What is the average quantity you usually sell at a go (in $\mathrm{kg}$ )?

9. Who makes decision on pigeon pea/chickpea sales?

i) Household head

ii) Spouse

iii) Joint decision between household head and spouse

iv) Another adult household member

10. Who decides on how the sales proceeds are spent?
i) Household head
ii) Spouse
iii) Joint decision between household head and spouse
iv) Another adult household member

11. What did you spend most of the sales proceeds on? [Tick two most important]
i) To pay school fees and other related expenses
ii) To purchase farm inputs
iii) To purchase farm inputs
iv) To purchase food
v) To pay medical expenses
vi) To pay for household expenses

12. What in your opinion are the TWO most pressing challenges in pigeon pea/chickpea marketing?
i) Low prices
ii) Missing markets
iii) Climatic changes and weather variability
iv) Lack of improved seeds
v) Pests and diseases for crops 


\section{REFERENCES}

Dillon, B. M. 2017. Selling Crops Early to Pay for School: A Large-Scale Natural Experiment in Malawi. http://dx.doi.org/10.2139/ssrn.2848003

Dzanja, J., M. Matita, H. Kankwamba, M. Dolislager, and D. Tschirley. 2016. Mapping Market Prospects for Grain Legumes in Malawi. Malawi Report No. 005. Global Center for Food Systems Innovation, Michigan State University, East Lansing, Michigan, USA.

India Pulses and Grains Association, accessed 18 December 2019, http://ipga.co.in/pulses-trade-flow-to-indian-subcontinent/

Monyo, E.S., and C.L.L. Gowda. 2014. Grain legumes strategies and seed roadmaps for select countries in Sub-Saharan Africa and South Asia: Tropical Legumes II Project Report. http://www.icrisat.org/TropicalLegumesIl/pdfs/November-2013.pdf

Monyo, E., O. Mponda, K. Ganesamurthy, H.D. Upadhyaya, and P. Janila. 2015. Bulletin of Tropical Legumes. Tropical Legumes III 2: 1 06.

Ochieng, D.O., R. Botha, and B. Baulch. 2019. Structure, conduct and performance of maize markets in Malawi. MaSSP Working Paper 29. Lilongwe, Malawi: International Food Policy Research Institute. https://doi.org/10.2499/p15738coll2.133375

StataCorp. undated. Stata: statistics and data analysis version 16.0, College Station, Texas.

Timmer C.P., W.P. Falcon, and S.R. Pearson. 1983. Food Policy Analysis. World Bank/Johns Hopkins University Press, Baltimore, MD.

Weber J, and Z. Tiba Z. 2017. Smallholder Risk Management Solutions (SRMS) in Malawi and Ethiopia: Value Chain Study and Design of a Replicable Business Model in Phalombe District, Southern Region of Malawi. Oxford Policy Management. Mimeo: 45 pp.

The Malawi Strategy Support Program (MaSSP) is managed by the International Food Policy Research Institute (IFPRI) and is made financially possible by the generous support of the American people through the United States Agency for International Development (USAID), and by the UK Department for International Development (DFID). This report has been prepared as an output for DFID. Any opinions expressed here belong to the author and are not necessarily representative of or endorsed by IFPRI.

\section{INTERNATIONAL FOOD POLICY RESEARCH INSTITUTE A world free of hunger and malnutrition}

